\title{
Effect of a Nationwide Universal HBV Vaccination Program and Catch-up Vaccination Campaign on HBV Prevalence in Children
}

\author{
Ülke Çapında Evrensel HBV Așılama Programının ve Yakalama Așı Kampanyasının \\ Çocuklarda HBV Prevalansı Üzerindeki Etkisi
}

\author{
๑ Selma Tosun'1, ๑ Serol Deveci², ๑ Erhun Kasırga3 \\ 1 University of Health Sciences Turkey, Izmir Bozyaka Training and Research Hospital, Clinic of Infectious Diseases and Microbiology, Izmir, Turkey \\ 2 Şehzadeler County Directorate of Health, Public Health Specialist, Manisa, Turkey \\ ${ }^{3}$ Manisa Celal Bayar University Faculty of Medicine, Department of Pediatric Gastroenterology, Manisa, Turkey
}

\begin{abstract}
Objectives: In infants vaccinated at birth against hepatitis B virus (HBV) in the context of a universal vaccination program, antibody titers may reduce over years, with a need for a booster dose at adolescence. The aim of the study was to evaluate the immunity and carriage status 8-10 years after 3 doses of HBV vaccine administered in infancy.

Materials and Methods: This was a descriptive, cross-sectional, community-based field study and was carried out between 2008 and 2011. Children with an anti-HBs titer $\leq 9 \mathrm{lU} / \mathrm{mL}, 10$ to $99 \mathrm{IU} / \mathrm{mL}$, and $\geq 100 \mathrm{IU} / \mathrm{mL}$ were categorized as negative, positive, and strongly positive.

Results: A total of 4,256 students born between 1995 and 2004 (age range: 7-12 years) were included in the study. Of the overall study group, 2099 (49.3\%) were male and 2157 (50.7\%) were female. In $62.3 \%$ of the children in group A (born in or before 1999), anti-HBs titers were above the protection limit $(\geq 10 \mathrm{IU} / \mathrm{mL})$, while this rate was $37.3 \%$ in group B (born in or after 2000 ), with a statistically significant difference $\left(p<0.00001, \chi^{2}=207.1841\right)$.

Conclusion: Three doses of HBV vaccination administered during the universal campaign is adequate with no need for booster doses, unless maternal hepatitis $B$ surface antigen positivity is present. Keywords: Universal HBV vaccination, children, booster dose
\end{abstract}

ÖZ

Amaç: Evrensel bir aşılama programı bağlamında doğumda hepatit B virüse (HBV) karşı aşılanan bebeklerde yıllar içinde antikor titreleri azalabilir ve ergenlik döneminde bir takviye dozuna intiyaç duyulabilir. Çalışmanın amacı, bebeklik döneminde uygulanan 3 doz HBV aşısından 8-10 yıl sonra bağışıklık ve taşıyıclık durumunu değerlendirmektir.

Gereç ve Yöntemler: Bu tanımlayıcı, kesitsel, toplum temelli bir saha çalışmasıdır ve 2008 ile 2011 yılları arasında yapılmıştır. AntiHBs titresi $\leq 9 \mathrm{IU} / \mathrm{mL}, 10$ ila $99 \mathrm{IU} / \mathrm{mL}$ ve $\geq 100 \mathrm{IU} / \mathrm{mL}$ olan çocuklar negatif, pozitif ve güçlü pozitif olarak sınıflandırımıştır.

Bulgular: Araştırmaya 1995-2004 yılları arasında (yaş aralığı: 7-12 yıl) doğan toplam 4.256 öğrenci dahil edilmiştir. Genel çalışma grubunun 2099'u (\%49,3) erkek ve 2157'si (\%50,7) kadındı. Grup A'daki (1999 ve öncesi doğumlu) çocukların \%62,3'ünde anti-HBs titreleri koruma sınııının üzerindeydi $(\geq 10 \mathrm{IU} / \mathrm{mL}$ ), grup B'de ise bu rakam (2000 ve sonrası doğumlu) istatistiksel olarak anlamlı bir farkla $(p<0,00001$, $\left.X^{2}=207.1841\right) \% 37,3$ idi.

Sonuç: Maternal hepatit B yüzey antijeni pozitifliği olmadıkça, evrensel aşılama programı kapsamında uygulanan üç doz HBV aşıSı, rapel dozlara gerek kalmadan yeterlidir.

Anahtar Kelimeler: Evrensel HBV aşılaması, çocuklar, güçlendirici doz

Tosun S, Deveci S, Kasırga E. Effect of a Nationwide Universal HBV Vaccination Program and Catch-up Vaccination Campaign on HBV Prevalence in Children. Viral Hepat J. 2021;27:148-152.

Address for Correspondence: Serol Deveci MD, Şehzadeler County Directorate of Health, Public Health Specialist, Manisa, Turkey Phone: +90 xxxxxxxxxxxxxxxxxxx E-mail: deveciserol24@hotmail.com ORCID ID: orcid.org/0000-0001-9084-8950 Received: 27.05.2021 Accepted: 21.09.2021

${ }^{\circ}$ Copyright 2021 by Viral Hepatitis Society / Viral Hepatitis Journal published by Galenos Publishing House. 


\section{Introduction}

Despite the decrease in the prevalence of hepatitis B virus (HBV) infection due to widespread protection and effective vaccination programs, it remains a significant global public health problem. There are an estimated 250-260 million cases of chronic HBV cases worldwide, and based on a 2015 review, nearly 887 thousand deaths have been recorded due to HBV related disease/ complications (1). Since early exposure to HBV is associated with very high rates of chronicity, a recommendation has been made to administer vaccination to all infants starting from birth $(2,3)$. The primary target of a universal $\mathrm{HBV}$ vaccination program is to prevent exposure to the virus. Since 1990, universal HBV vaccination has been successfully undertaken, with a worldwide coverage rate of $84 \%$ for 3 doses as of 2015 (4).

Several studies have reported very successful outcomes regarding the efficiency of the universal hepatitis B vaccination. In the most successful example of Taiwan, the campaign had been initiated in 1988 with the vaccination of newborns, with a nationwide coverage achieved in 1992. One study conducted 22 years after the initiation of the universal vaccination showed that the hepatitis B surface antigen ( $\mathrm{HBsAg}$ ) positivity rate declined from $5.6 \%$ during the pre-vaccination period to less than $1 \%$ after the program (5).

In our country, all newborns receive hepatitis B vaccination since 1998 in the context of the Turkish National Vaccination Program, like Thailand (6). Manisa in western Turkey which is located in, hepatitis B carrier in the Aegean Region is estimated 3:47 ratio \%; shows mesoendemic propagation feature (7). Although previous studies from Turkey showed a decline in HBsAg positivity rates after the initiation of widespread vaccination program, this infection remains an important health problem in certain endemic regions $(4,7)$. Again, following the initiation of universal HBV vaccination, the Ministry of Health initiated another HBV vaccination campaign involving $8^{\text {th }}$ grade primary school students in 2005-2006 academic year as a transition to an adolescent vaccination program, with a subsequent 3-dose vaccination program (catch-up program) in 2007-2008 involving all primary school students between $3^{\text {rd }}$ and $8^{\text {th }}$ grades as well as high school students, as a coverage for inadequate or missing doses. During this campaign, a 3-dose HBV vaccination was repeated in primary school children born in or before 1999, assuming that there might have been cases who could not adhere to the program, had delayed vaccination, or had no vaccination at all during the nationwide HBV vaccination program initiated in 1998. Also, throughout the campaign, children born in 2000 and later did not receive repeated HBV vaccination.

This study was undertaken to assess the changes in HBV prevalence among children after initiation of the universal HBV vaccination from newborn, and to compare anti-HBs responses between those who never received additional vaccination after infancy and those who received repeated vaccination in the campaign.

\section{Materials and Methods}

This was a descriptive, cross-sectional, community-based field study. The target sample population consisted of primary school students in the provincial center of Manisa and Turgutlu district. The data on the current number of students was obtained from Provincial Education Center to determine the schools to be included in the study and to categorize study groups according to socioeconomic and cultural status (as high, intermediate, and low), with stratification based on the year of birth. Since primary education is compulsory in public schools and students are registered to schools based on address; schools are stratified in terms of socioeconomic level according to the region in which they are located. The population of the research was 25,871 students and the sample size consisted of 4,256 students.

The study protocol was approved by the Ethics Committee of Izmir Atatürk Training and Research Hospital (approval number: B41SM4350015-009/263, date: 21.09.2007) as well as the Ministry of Health. Verbal consent was obtained from the participants.

Anti-HBs as an indicator of immunity and HBsAg as an indicator of carriage are the main outcome measures of this study.

During school visits, total of $5 \mathrm{cc}$ of blood sample was obtained from each participant, first to assess anti-HBs using micro-EIA method (Sorin, Italy), and then to further evaluate anti-HBc immunoglobulin $\mathrm{G}(\mathrm{lgG})$ and $\mathrm{HBsAg}$ in those with an anti-HBs of $\leq 9 \mathrm{lU} / \mathrm{mL}$. Children with an anti-HBs titer $\leq 9 \mathrm{IU} / \mathrm{mL}, 10$ to $99 \mathrm{IU} /$ $\mathrm{mL}$, and $\geq 100 \mathrm{IU} / \mathrm{mL}$ were categorized as negative, positive, and strongly positive. HBsAg and anti-HBc lgG were tested in those with an anti-HBs titer of $\leq 9 \mathrm{lU} / \mathrm{mL}$. At the end of the 3-year study period (2008-2011), the results were analyzed in view of the repeated vaccinations during the catch-up campaign endorsed by the Ministry of Health as well as birth year data.

\section{Statistical Analysis}

Analysis of data was done with SPSS version 24.0. Cross tabulation was used to examine the relationships occurring between variables. Associations were tested using chi-square analysis.

\section{Results}

A total of 4,256 students born between 1995 and 2004 (age range: $7-12$ years) were included in the study. Of the overall study group 2099 (49.3\%) were male and 2157 (50.7\%) were female. Group A (born in or before 1999, with repeated vaccination during the catch-up campaign) consisted of 3,161 children and group B (born in or after 2000, with no repeated HBV vaccination after the initial 3 doses in infancy) consisted of 1,095 children.

In $62.3 \%$ of the children in group A, i.e. among those who received a second series of vaccinations (at least 1 dose or 3 doses) after vaccination at infancy, anti-HBs titers were above the protection limit $(\geq 10 \mathrm{IU} / \mathrm{mL}$ ), while this figure was $37.3 \%$ in group $B$, i.e. those who had not received further vaccination, with the difference being significant ( $p<0.00001, c 2=207.1841$ ) (Table 1).

When low and high positivity status for anti-HBs was considered, $62.7 \%$ of the children in group B were found to have anti-HBs titers below the protection limit, with a significant difference between the groups, together with a lower proportion (14.4\%) of children in group B with strong positivity for anti-HBs (anti-HBs >100 IU/ $m L)(p<0.00001, c 2=265.3519)$. However, the two groups were comparable with regard to the proportion of subjects with positivity (10-99 IU/mL) (Table 2).

Antibody levels were evaluated according to the socioeconomic 


\begin{tabular}{|c|c|c|c|}
\hline HBV vaccination history & $\leq 9 \mathrm{mIU} / \mathrm{mL}$ & $\geq 10 \mathrm{mlU} / \mathrm{mL}$ & Total \\
\hline \multicolumn{4}{|l|}{ Group A } \\
\hline \multicolumn{4}{|l|}{ Group B } \\
\hline
\end{tabular}

level of the students (Table 3). Accordingly, the proportion of nonimmunities increases as the socio-economic level deteriorates; according to the socio-economic level, these rates are at the same order high 39.5\% (425), medium 40.0\% (468), low 49.0\% (985). Conversely, the proportion of those with an immunity higher than $100 \mathrm{IU} /$ mlincreases as the socioeconomic level improves; in the same order, these rates were set as low 30.9\% (622), medium $31.4 \%(367)$ and $37.2 \%$ (399) high.

Twenty-three children $(0.5 \%)$ were found to have HBsAg positivity. The birth year and gender distribution of these cases with HBsAg positivity are shown in Table 4.

Among HBsAg positive children, 17 were born in or before 1998, when universal HBV vaccination was initiated, and only 6 were born after 1999. Again, of these 23 children, 21 had maternal HBsAg positivity, one had paternal HBsAg positivity, and one had sibling HBsAg positivity.

Four-hundred and fifty-six children with anti-HBs titers below the protection level could be reached, and when the anti-HBs testing was repeated 4 to 6 weeks after a single dose HBV vaccination, an anamnestic response was found in 440 (96.4\%) of these, with all children having anti-HBs titer of greater than 100 $\mathrm{IU} / \mathrm{mL}$. All of the 16 children who failed to develop an anamnestic response after the first follow-up testing achieved an anti-HBs response following the second HBV vaccination.

\section{Discussion}

Several studies have established that in subjects who received 3-doses of HBV vaccination during infancy, the immune memory can be maintained for prolonged periods of time, even if anti-HBs loss occurs (9). In Pakistan, a universal HBV vaccination program was initiated in 2002, with a dosing schedule involving vaccinations at 6-10 and 14 weeks of life. Of the 200 children vaccinated using this scheme, 58\% were found to have protective anti-HBs levels when the protective properties of the vaccination was assessed in 2014, and in half of the children between ages 8 and 10 years, antiHBs levels were $\leq 10 \mathrm{lU} / \mathrm{mL}$. When a single dose vaccination was administered, all children developed anamnestic response (10).

In a Taiwanese study between 2008 and 2012, blood samples were obtained from 887 adolescents born between 1993 and 1997 and vaccinated during infancy, and the proportion of subjects with adequate anti-HBs titer and HBsAg positivity were found to be $34.7 \%$ and $0.7 \%$, respectively. A booster dose was given in a total of 501 children with anti-HBs titers below the protection limit, with $94 \%$ of these developing anamnestic response 6 months after vaccination (11).

In a multi-center phase 4 study from Germany, blood samples were obtained from children aged between 12-13 years who were vaccinated during infancy using a hexavalent vaccine (HBV + $\mathrm{DTPa}+$ IPV + Hib). Among the overall population of 293 children, $60.5 \%$ had an anti-HBs titer $\geq 10 \mathrm{IU} / \mathrm{mL}$, and $97.6 \%$ of those without adequate antibody levels developed anamnestic response following a single booster dose (12).

In another study where blood tests were performed among 293 adolescents 15 to 15 years after vaccination, $71.2 \%$ were found to have adequate anti-HBs levels, with a mean anti-HBs titer of $26.5 \mathrm{lU} / \mathrm{mL}$ (range: 21.4-32.8). One month after a booster dose, the mean anti-HBs titers increased above $100 \mathrm{lU} / \mathrm{mL}$. Thus, the authors suggested that immunity was maintained 15 to 16 years after vaccination, and that a good response was achieved after the booster dosing (13).

In a recent study from Korea, laboratory results in 19.072 individuals were tested between 2000 and 2015. Study participants were divided into two groups. The first group consisted of those born before 2005 who received both the recombinant and plasmaderived vaccines, while the second group included subjects born after 2005 who received only the recombinant vaccine. Overall, 55.8\% of the population had anti-HBs positivity, and the corresponding figures in the first and second groups were $53.0 \%$ and $78.1 \%$, respectively. In children with loss of anti-HBs titers, anti-HBs was found to develop following a single booster dose. It was concluded that lifelong protection is important for HBV infections and therefore a booster dose may be needed during adolescence (14).

In our country, a significant reduction in cases with acute HBV infection was observed after initiation of the nationwide HBV vaccination program, particularly among pediatric and adolescent populations. In a study looking at the contributions of this vaccination program published in 2012, the reported cases of acute HBV infection between 1990 and 2012 were analyzed and a dramatic decline in acute HBV infections in all patients under 15 years of age was identified during the time period between 1997 and 2014 (8).

Similarly, we also observed statistically significantly higher anti-HBs titers among children who received repeated vaccination approximately 10 years after the 3-dose HBV vaccination during infancy, as compared to those who never received booster doses. Following a single booster dose among children with an anti-HBs tire of $\leq 10 \mathrm{IU} / \mathrm{mL}, 96.4 \%$ developed an anamnestic response. A booster dose administered upon decline and loss of antibody titers in previously vaccinated individuals was associated with a significant increase in antibody titers, while in those with high initial anti-HBs levels, this results in a more prolonged maintenance of 


\begin{tabular}{|c|c|c|c|c|}
\hline HBV vaccination history & $\leq 9 \mathrm{mlU} / \mathrm{mL}$ & $10-99 \mathrm{mlU} / \mathrm{mL}$ & $\geq 100 \mathrm{mlU} / \mathrm{mL}$ & Total \\
\hline \multicolumn{5}{|l|}{ Group A } \\
\hline \multicolumn{5}{|l|}{ Group B } \\
\hline
\end{tabular}

\begin{tabular}{|c|c|c|c|c|}
\hline Socioeconomic status & $\leq 9 \mathrm{mIU} / \mathrm{mL}$ & $10-99 \mathrm{mIU} / \mathrm{mL}$ & $\geq 100 \mathrm{mIU} / \mathrm{mL}$ & Total \\
\hline High & $425(39.5 \%)$ & $251(23.3 \%)$ & $399(37.2 \%)$ & $1075(25.3 \%)$ \\
\hline Medium & $468(40.0 \%)$ & $334(28.6 \%)$ & 367 (31.4\%) & $1169(27.5 \%)$ \\
\hline Low & $985(49.0 \%)$ & $405(20.1 \%)$ & $622(30.9 \%)$ & $2012(47.2 \%)$ \\
\hline Total & $1878(44.1 \%)$ & $990(23.3 \%)$ & $1388(32.6 \%)$ & $4256(100 \%)$ \\
\hline
\end{tabular}

\begin{tabular}{|l|l|l|l|}
\hline \multicolumn{2}{|l|}{ Table 4. Age and gender distribution in children with HBsAg positivity (n=23) } & Boy (\%a) & Total (\%b) \\
\hline Year of birth & Girl (\%a) & $1(10.0 \%)$ & $3(13.0 \%)$ \\
\hline 1995 & $2(15.4 \%)$ & - & $4(17.4 \%)$ \\
\hline 1996 & $4(30.8 \%)$ & $2(20.0 \%)$ & $2(8.7 \%)$ \\
\hline 1997 & - & $4(40.0 \%)$ & $8(34.8 \%)$ \\
\hline 1998 & $4(30.8 \%)$ & $1(10.0 \%)$ & $2(8.7 \%)$ \\
\hline 1999 & $1(7.7 \%)$ & $2(20.0 \%)$ & $4(17.4 \%)$ \\
\hline 2000 & $2(15.4 \%)$ & $10(56.5 \%)$ & $23(100.0 \%)$ \\
\hline Total & $13(43.5 \%)$ & & \\
\hline a: With in gender, b:With in total, HBsAg: Hepatitis B surface antigen & & \\
\hline
\end{tabular}

the titers $(15,16)$. These observations suggest that immunologic memory is formed as a result of the vaccination during infancy, and that the protective effect may last many years.

In $23(0.5 \%)$ of the 4,256 children included in the study, HBsAg positivity was found. Seventeen of these children were born prior to the nationwide vaccination program, while six were born after that. Of these 23 children 21 had maternal, one had paternal, and one another had sibling positivity for HBsAg. In South East Asian countries where HBsAg positivity rates are high, the primary factor for persistence of HBsAg positivity among children (although at low percentage) and unresponsiveness to vaccination was reported to be maternal HBsAg positivity, which, according to the authors, should be the primary focus $(17,18)$.

Taiwan is an hyperendemic country for HBV infections where universal HBV vaccination was started in 1984, followed by 5 different sero-epidemiologic studies at $0,5,10,15$, and 20 years after the initiation of the program. These studies showed that the program was remarkably successful, with $\mathrm{HBsAg}$, anti-HBc lgG, and anti-HBs positivity rates of $10.0 \%, 28.0 \%$, and $24.5 \%$, respectively at the time of study initiation in 1984 , decreasing to $0.9 \%, 7.0 \%$, and $55.9 \%$, respectively in 2009 . A more recent study conducted at 25 years after initiation of the program involved 3332 individuals under 30 years of age with inclusion of participants from each of the 5 different study cohorts described above, and showed further reduction in HBsAg positivity rates, with a vaccination failure rate of $86 \%$ in the presence of maternal HBsAg positivity (19).

These observations again underscore the importance of screening pregnant women for HBsAg and administration of appropriate immunization (vaccination + hepatitis B immune globulin) at the time of labor in carrier mothers.

The relationship between socio-economic status and immunity levels is thought to be related to the behaviors of students' families using preventive health services, including immunization. With the implementation of the universal HBV vaccination campaign, the increase in the coverage of immunization services provides herd immunity by eliminating the possible negative effects of socioeconomic differences.

\section{Study Limitations}

The limitations of the study: Participants are not aware of their previous hepatitis B participants are not aware of their previous hepatitis B vaccination status as they were assumed to have been vaccinated in the National Vaccination Program. Another weakness of the study is that it did not include students who were absent from school for any reason. 
The strengths of the study are showing the trend effect between weak and strong immunity and socioeconomic levels, as well as demonstrating the effectiveness of Universal HBV Immunization.

\section{Conclusion}

Twenty-two years after initiation of a nationwide HBV vaccination program, a significant decrease in $\mathrm{HBsAg}$ positivity among primary school children aged between 7 and 14 years has been detected. We may assume that our results can be extrapolated to children in other geographical areas in Turkey as a result widespread vacination. However, in order to maintain this success, same meticulous care should continue for vaccination of newborns. Detection of maternal HBsAg positivity in 21 out of 23 children with HBsAg positivity one more time underlines the importance of administering vaccination and hepatitis B hyperimmunoglobulin to babies born to carrier mothers.

Acknowledgments: We would like to express our gratitude to all medical personnel for blood collection and the designation of data collection instruments. Also, thanks also to the Viral Hepatitis Society of Manisa, for their financial support.

\section{Ethics}

Ethics Committee Approval: The study protocol was approved by the Ethics Committee of Izmir Atatürk Training and Research Hospital (approval number: B41SM4350015-009/263, date: 21.09.2007) as well as the Ministry of Health.

Informed Consent: Verbal consent was obtained from the participants.

Peer-review: Externally peer-reviewed.

\section{Authorship Contributions}

Surgical and Medical Practices: S.T., Concept: S.T., S.D., Design: S.T., S.D., Data Collection or Processing: S.T., Analysis or Interpretation: S.D., Literature Search: S.T., S.D., E.K., Writing: S.T., S.D., E.K

Conflict of Interest: No conflict of interest was declared by the authors.

Financial disclosure: The authors declare no financial support.

\section{References}

1. Global health sector strategy on viral hepatitıs 2016-2021 towards endıng viral hepatitıs who 2016 http://apps.who.int/iris/ bitstream/10665/246177/1/WHO-HIV-2016.06-eng.pdf?ua=1

2. Rantala M, van de Laar MJ. Surveillance and epidemiology of hepatitis B and C in Europe - a review. Euro Surveill. 2008;13:18880.

3. WHO. HBV fact sheet (accessed: 04 September, 2017). http:// www.who.int/mediacentre/factsheets/fs204/en/

4. Tosun S. Viral hepatitis B epidemiology in the World and Turkey. In: Güner R, Tabak F, (Eds). Viral Hepatit 2018. A publication by the taskforce against viral hepatitis. Istanbul: Istanbul Medical Health and Publishing Co; 2018. p. 13-48.

5. Posuwan N, Wanlapakorn N, Sa-Nguanmoo P, Wasitthankasem R, Vichaiwattana P, Klinfueng S, Vuthitanachot V, Sae-Lao S, Foono
M, Fakthongyoo A, Makaroon J, Srisingh K, Asawarachun D, Owatanapanich S, Wutthiratkowit N, Tohtubtiang K, Yoocharoen P, Vongpunsawad S, Poovorawan $Y$. The success of a Universal hepatitis B immunization program as part of Thailand's EPI after 22 years' implementation. PLoS One. 2016;11:e0150499.

6. Turkish Ministry of Health, General Directorate for Basic Health Services, Notice for the Expanded Vaccination Program (Standing Notice); 2008.

7. Toy M, Önder FO, Wörmann T, Bozdayi AM, Schalm SW, Borsboom GJ, van Rosmalen J, Richardus JH, Yurdaydin C. Age- and region-specific hepatitis $\mathrm{B}$ prevalence in Turkey estimated using generalized linear mixed models: a systematic review. BMC Infect Dis. 2011:11:337.

8. Ay P, Torunoglu MA, Com S, Çipil Z, Mollahaliloğlu S, Erkoc Y, Dilmen U. Trends of hepatitis B notification rates in Turkey, 1990 to 2012. Euro Surveill. 2013;18:20636.

9. Spada E, Roman L, Tosti ME, Zuccaro O, PaladiniS, Chironna M, Coppola RC, Cuccia M, Mangione R, Marrone F, Negrone FS, Parlato A, Zamparo E, Zotti CM, Mele A, Zanetti AR; Study Group. Hepatitis $B$ immunity in teenagers vaccinated as infants: an Italian 17-year follow-up study. Clin Microbiol Infect. 2014;20:0680-686.

10. Afzal MF, Sultan MA, Saleemi Al. immune response and anamnestic immune response in children after a 3-dose primary hepatitis B vaccination. J Ayub Med Coll Abbottabad. 2016;28:715-717.

11. Chen YS, Chu CH, Wang JH, Lin JS, Chang YC. Predictors of booster response to hepatitis $B$ vaccine at 15 years of age: A crosssectional school-based study. Pediatr Neonatol. 2016;57:302-309.

12. Behre U, Van Der Meeren O, Crasta P, Hanssens L, Mesaros N. Lasting immune memory against hepatitis $B$ in 12-13-year-old adolescents previously vaccinated with 4 doses of hexavalent DTPa-HBV-IPV/Hib vaccine in infancy. Hum Vaccin Immunother. 2016;12:2916-2920.

13. Van Der Meeren O, Behre U, Crasta P. Immunity to hepatitis B persists in adolescents 15-16 years of age vaccinated in infancy with three doses of hepatitis B vaccine. Vaccine. 2016;34:27452749 .

14. Kim YJ, Li P, Hong JM, Ryu KH, Nam E, Chang MS. A single center analysis of the positivity of hepatitis B antibody after neonatal vaccination program in Korea. J Korean Med Sci. 2017;32:810-816.

15. Mast EE, Weinbaum CM, Fiore AE, Alter MJ, Bell BP, Finelli $L$, Rodewald LE, Douglas JM Jr, Janssen RS, Ward JW; Advisory Committee on Immunization Practices (ACIP) Centers for Disease Control and Prevention (CDC). A comprehensive immunization strategy to eliminate transmission of hepatitis B virus infection in the United States: recommendations of the Advisory Committee on Immunization Practices (ACIP) Part II: immunization of adults. MMWR Recomm Rep. 2006;55:1-33.

16. Tosun S. Hepatitis B vaccination, and outcome of hepatitis b vaccination in our country. Textbook of Viral Hepatitis. A Publication by the Taskforce Against Viral Hepatitis. Istanbul: Istanbul Medical Publishing; 2018.

17. Lin DB, Wang HM, Lee YL, Ling UP, Changlai SP, Chen CJ. Immune status in preschool children born after mass hepatitis $B$ vaccination program in Taiwan. Vaccine. 1998;16:1683-1687.

18. Ni YH, Huang LM, Chang MH, Yen CJ, Lu CY, You SL, Kao JH, Lin YC, Chen HL, Hsu HY, Chen DS. Two decades of universal hepatitis B vaccination in Taiwan: Impact and implication for future strategies. Gastroenterology. 2007;132:1287-1293.

19. Ni YH, Chang MH, Wu JF, Hsu HY, Chen HL, Chen DS. Minimization of hepatitis $\mathrm{B}$ infection by a 25 -year universal vaccination program. J Hepatol. 2012:57:730-735. 